\title{
Heat remains unaccounted for in thermal physiology and
}

\section{climate change research [version 1; peer review: 1 approved, 1 \\ approved with reservations]}

\author{
Andreas D. Flouris (iD) 1,2, Glen P. Kenny² \\ ${ }^{1}$ FAME Laboratory, Department of Exercise Science, University of Thessaly, Trikala, Greece \\ ${ }^{2}$ Human and Environmental Physiology Research Unit, School of Human Kinetics, University of Ottawa, Ottawa, ON, Canada
}

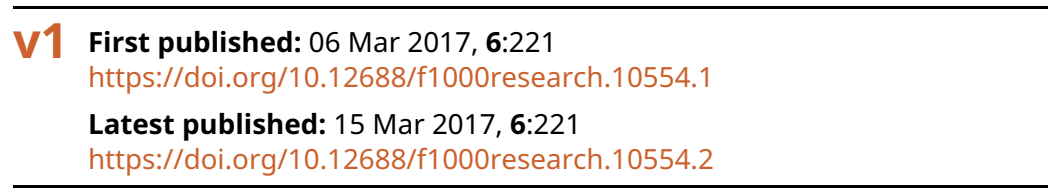

\section{Abstract}

In the aftermath of the Paris Agreement, there is a crucial need for scientists in both thermal physiology and climate change research to develop the integrated approaches necessary to evaluate the health, economic, technological, social, and cultural impacts of $1.5^{\circ} \mathrm{C}$ warming. Our aim was to explore the fidelity of remote temperature measurements for quantitatively identifying the continuous redistribution of heat within both the Earth and the human body. Not accounting for the regional distribution of warming and heat storage patterns can undermine the results of thermal physiology and climate change research. These concepts are discussed herein using two parallel examples: the so-called slowdown of the Earth's surface temperature warming in the period 1998-2013; and the controversial results in thermal physiology, arising from relying heavily on core temperature measurements. In total, the concept of heat is of major importance for the integrity of systems, such as the Earth and human body. At present, our understanding about the interplay of key factors modulating the heat distribution on the surface of the Earth and in the human body remains incomplete. Identifying and accounting for the interconnections among these factors will be instrumental in improving the accuracy of both climate models and health guidelines.

\section{Keywords}

global warming, hiatus, temperature, ocean heat uptake, hyperthermia

\section{Open Peer Review \\ Approval Status \\ 1} 2

version 2

(revision)

15 Mar 2017

version 1

06 Mar 2017

view view

1. Juha Oksa (iD), Finnish Institute of

Occupational Health, Oulu, Finland

2. Eugene A. Kiyatkin, National Institutes of

Health (NIH), Baltimore, USA

Keaton T. Cameron-Burr, National Institutes of Health (NIH), Baltimore, USA

Any reports and responses or comments on the article can be found at the end of the article.

This article is included in the Climate gateway. 
Corresponding author: Andreas D. Flouris (andreasflouris@gmail.com)

Competing interests: No competing interests were disclosed.

Grant information: This work has received funding from the European Union's Horizon 2020 research and innovation programme (grant no., 668786).

The funders had no role in study design, data collection and analysis, decision to publish, or preparation of the manuscript.

Copyright: $\odot 2017$ Flouris AD and Kenny GP. This is an open access article distributed under the terms of the Creative Commons Attribution License, which permits unrestricted use, distribution, and reproduction in any medium, provided the original work is properly cited. Data associated with the article are available under the terms of the Creative Commons Zero "No rights reserved" data waiver (CC0 1.0 Public domain dedication).

How to cite this article: Flouris AD and Kenny GP. Heat remains unaccounted for in thermal physiology and climate change research [version 1; peer review: 1 approved, 1 approved with reservations] F1000Research 2017, 6:221

https://doi.org/10.12688/f1000research.10554.1

First published: 06 Mar 2017, 6:221 https://doi.org/10.12688/f1000research.10554.1 


\section{Introduction}

The Agreement reached in Paris during December 2015, under the auspices of the United Nations Framework Convention on Climate Change, binds countries to "...pursue efforts to limit the [global] temperature increase to $1.5^{\circ} \mathrm{C}$ above pre-industrial levels". The same document also invites the Intergovernmental Panel on Climate Change (IPCC) to “...provide a special report in 2018 on the impacts of global warming of $1.5^{\circ} \mathrm{C}$ above pre-industrial levels and related global greenhouse gas emission pathways" (full document: Paris Agreement, FCCC/CP/2015/10/Add.1, annex. UNFCCC secretariat. Retrieved 20 January 2017). In doing so, the IPCC must provide useful and robust evidence, which can be a challenge, as previously suggested (Hulme, 2016), given the limited analyses conducted thus far on the global and regional impacts of $1.5^{\circ} \mathrm{C}$ warming. Another challenge for the IPCC, and the scientific community, is to develop the integrated approaches necessary to evaluate the health, economic, technological, social, and cultural impacts of $1.5^{\circ} \mathrm{C}$ warming. As illustrated by a recent scientific conundrum (described in the following section), the concept of heat should be central to these integrated approaches. In this light, the objective of this article is to explore the fidelity of remote temperature measurements for quantitatively identifying the continuous redistribution of heat within both the Earth and the human body.

\section{Unaccounted heat in climate research}

Hailed as "one of the biggest mysteries in climate science" (Tollefson, 2013), the slowdown of the Earth's surface temperature warming in the period 1998-2013 undermined, for a number of years, the idea that human-generated greenhouse gases are the main driver and cause of climate change (Nieves et al., 2015). During this period, the existing climate models were unable (on average) to reproduce the observed atmospheric temperature trend. Several theories were proposed to explain this surface temperature "hiatus". One of the first explanations put forth was that it is normal for warming rates to plateau occasionally (Trenberth, 2015). Other factors that were extensively investigated included the increased volcanic activity and the high levels of air pollution in China during the hiatus period, since atmospheric particles reflect more of the Sun's energy back into space (Solomon et al., 2011). The ever-increasing decline in solar activity since 2000 was also considered as a possibility, since it reduces the amount of energy reaching the Earth (Ineson et al., 2015). Ultimately, in 2015, Nieves and colleagues showed that what was interpreted as a change in the planet's warming rate was, in fact, a redistribution of heat within the ocean (Nieves et al., 2015). Specifically, Nieves et al., showed that heat moved from the surface of the Pacific Ocean to the deeper layers of the Western Pacific and Indian Oceans. As a result, the net ocean heat uptake remains dangerously high (Nieves et al., 2015), and the rate of global warming may have actually increased during the hiatus period (IPCC, 2014). Unfortunately, the findings of Nieves et al., were soon to be confirmed by the record-breaking temperatures throughout 2015 and 2016 (https://www.nasa.gov/ press-release/nasa-noaa-data-show-2016-warmest-year-on-recordglobally).

Research aiming to understand the 1998-2013 hiatus was significantly benefited by studies into the causes of a much longer hiatus observed from the 1950s to the 1970s. During this period, global mean surface temperature remained approximately constant despite increased burden from anthropogenic factors. Interestingly, as in the case of the 1998-2013 hiatus, the ocean heat uptake was a very important contributing factor to this longer offsetting of the warming rate (England et al., 2014). This is not surprising. Ocean circulation changes have a vast impact on the geographical distribution of warming and heat storage patterns, which ultimately affect the planet's surface climate (Nieves et al., 2015). Measuring atmospheric temperature at specific regions can only indicate regional changes in heat content and - as in the case of the 1998-2013 hiatus - can lead to wrong conclusions about the planet's warming rate.

\section{Unaccounted heat in thermal physiology research}

The effect of ocean heat uptake on the geographical distribution of warming and the heat storage patterns on the surface of the planet closely mirror thermodynamic processes within the human body. Blood within the circulatory system is constantly redistributed, not only to meet the demands of metabolic and immune processes, but also to move heat from/to specific regions and maintain thermal homeostasis (Flouris et al., 2006; Flouris \& Cheung, 2009; Kenny \& Jay, 2013). These blood flow adaptations can reach dramatic proportions in the human body. For instance, during rest in thermoneutral conditions, $0.5 \mathrm{~L} / \mathrm{min}$ of blood $(5-10 \%$ of cardiac output) supply the skin (Lossius et al., 1993). Nevertheless, during heat stress, up to $8 \mathrm{~L} / \mathrm{min}$ of blood (50-70\% of cardiac output) is directed to the cutaneous circulation, mainly by restricting visceral and renal blood flow (Lossius et al., 1993). These enormous changes in blood flow have a vast effect on the regional distribution of heat and the heat storage patterns, which ultimately affect the entire body's thermal homeostasis. Therefore, measuring temperature in specific regions of the body, such as the rectum, esophagus, or the visceral organs, can only indicate regional changes in heat content (Flouris \& Cheung, 2010; Flouris \& Cheung, 2011; Kenny et al., 2015; Kenny et al., (In press); Taylor et al., 2014; Webb, 1986). Nevertheless, for more than 100 years, scientists have been using such measurements to make assumptions about the thermal strain across the entire body. Moreover, the currently recommended criterion when addressing heat-related health risks is a single temperature measurement in the rectum (World Meteorological Organization and World Health Organization, 2015).

A recent paper on occupational heat exposure (Meade et al., 2016) provides an example of the limitations inherent in single temperature measurements used to assess whole-body thermal strain. In hot environments, industries must take preventive measures to protect their workers against heat-related injury and illness. To determine what protections should be used, they may follow guidelines from bodies of knowledgeable experts. One such set of guidelines comes from the American Conference of Governmental Industrial Hygienists (ACGIH, 2007); they recommend that industries employ the Threshold Limit Values (TLV) for work in hot environments. The TLV consider both environmental conditions and work demands, with the goal of maintaining the internal body temperatures of workers within safe limits. However, it is unclear if these guidelines adequately protect workers. The aforementioned recent study applied the TLV recommendations for work-rest periods by having a group of participants perform moderate intensity work bouts in progressively hotter environments. According to the $\mathrm{TLV}$, as environmental heat levels increased, the recovery periods 
between work bouts were lengthened (Meade et al., 2016). Once these guidelines are applied, the TLV predict that the body's core temperature should be minimally affected. Yet, the core temperatures of the young physically active adults tested in this study rose continuously. Overall, the findings demonstrated that, under the work conditions tested, the TLV do not adequately protect workers from potentially dangerous increases in their internal temperatures. As mentioned above, these findings are likely ascribable to a heterogeneous distribution of heat within the body's 'core' tissues (i.e., organs, muscles) (Taylor et al., 2014), which may be influenced by the profound thermoregulatory and cardiovascular (the majority of heat transfer within the body occurs through convective transfer via blood) alterations associated with recovery from exercise (Halliwill et al., 2014; Kenny \& Journeay, 2010; Kenny \& Jay, 2013). If this peripheral heat storage is transferred from the tissues to the body's core, it presents an increased risk of heat related illness and injury during work. Therefore, the TLV guidelines should be revised, especially given the warming climate and the increase in the frequency and intensity of extreme heat events.

\section{Heat parallels in the two disciplines}

Recognition that ocean heat uptake plays a key role in modulating human-caused global surface warming has been one of the many valuable ancillary benefits of research aiming to understand the 1998-2013 hiatus. Identifying and accounting for errors in ocean heat uptake estimations has been vital in this improved understanding (Fyfe et al., 2016) and will be instrumental in improving the accuracy of future climate predictions. For instance, climate models accounting for these recent advances suggest a transition to a positive phase of the Interdecadal Pacific Oscillation, which will increase the warming rate of global surface temperature (Hawkins et al., 2014; Thoma et al., 2015). Similarly to climate studies, thermal physiology research employing calorimetric methods has shown that temperature measurements at a single region of the body's core do not (on average) reflect whole-body thermal strain [(Flouris \& Cheung, 2010; Kenny et al., 2013; Kenny et al., (In press); Meade et al., 2016; Stapleton et al., 2014; Stapleton et al., 2015; Webb, 1986), including reviews (Benzinger et al., 1961; Taylor et al., 2014; Webb, 1995)]. In addition to their limited accuracy, such measurements contain a significant time lag, which makes them less effective for scientific purposes and potentially problematic when used in health-related settings. Indeed, core temperature readings are notorious for responding with delays of 10-30 minutes (Kenny \& Jay, 2013), even when the human body undergoes extreme discomfort, such as a sudden passive immersion in $12^{\circ} \mathrm{C}$ water (Flouris \& Cheung, 2009). Interestingly, a similar time lag exists in the Earth's warming rate phenomenon, since $80 \%$ of the heat added to the climate system is being taken up by the ocean (IPCC, 2014). As a result, even if greenhouse gas concentrations were to drastically reduce, the planet would continue to warm for many decades (IPCC, 2014).

\section{Concluding remarks}

Scientists in thermal physiology and climate change research are measuring temperature but, very often, they are missing the heat. Relying on indicators that provide a less accurate and/or delayed view of a natural phenomenon is dangerous. In the case of climate change research, interpreting the slowdown of atmospheric temperature rise during 1998-2013 as a change in the planet's warming rate would have given way to lax policies in environmental monitoring. In the 15 years required to identify the key factors involved, obtain more accurate data, and reassess the situation, these policies could have produced devastating effects and pushed the planet's climate into unchartered territory. In a similar way, interpreting the minimal temperature changes often observed in a single region of the body's core as a lack of whole-body thermal strain, gives way to an impassable abyss of controversial results in scientific experiments and, even worse, ineffective guidelines for work in hot environments, as well as delayed application of treatment in occupational or clinical settings.

The concept of heat is of major importance for the integrity of systems, such as the Earth (IPCC, 2014; Nieves et al., 2015) and the human body (Borden \& Cutter, 2008; Flouris \& Piantoni, 2015; Luber \& McGeehin, 2008). At present, our understanding about the interplay of key factors modulating the heat distribution on the surface of the Earth and in the human body remains incomplete. Identifying and accounting for the interconnections among these factors will be instrumental in improving the accuracy of both climate models and health guidelines. In the aftermath of the Paris Agreement, there is a need for scientists in both thermal physiology and climate change research to embrace integrated approaches that provide comprehensive views of the natural phenomena under study, taking into account the distribution of warming and heat storage patterns. For on that may depend the future in these scientific disciplines and, possibly, the future of the planet.

\section{Author contributions}

Both authors conceived the main idea of this paper. ADF prepared the first draft of the manuscript. Both authors revised the draft manuscript and have agreed to the final content.

\section{Competing interests}

No competing interests were disclosed.

\section{Grant information}

This work has received funding from the European Union's Horizon 2020 research and innovation programme (grant no., 668786).

The funders had no role in study design, data collection and analysis, decision to publish, or preparation of the manuscript. 
ACGIH: Heat stress and strain. In: Documentation of the Threshold Limit Values for Physical Agents Documentation. Cincinnati (OH): ACGIH; 2007.

Benzinger TH, Pratt AW, Kitzinger C: The thermostatic control of human metabolic heat production. Proc Natl Acad Sci U S A. 1961; 47(5): 730-739. PubMed Abstract | Free Full Text

Borden KA, Cutter SL: Spatial patterns of natural hazards mortality in the United States. Int J Health Geogr. 2008; 7: 64.

PubMed Abstract | Publisher Full Text | Free Full Text

England $\mathrm{MH}, \mathrm{McGregor} \mathrm{S}$, Spence $\mathrm{P}$, et al.: Recent intensification of wind-driven circulation in the pacific and the ongoing warming hiatus. Nature Clim Change. 2014; 4: 222-227.

Publisher Full Text

Flouris AD, Cheung SS, Fowles JR, et al.: Influence of body heat content on hand function during prolonged cold exposures. J Appl Physiol (1985). 2006; 101(3): 802-808.

PubMed Abstract | Publisher Full Tex

Flouris AD, Cheung SS: Influence of thermal balance on cold-induced vasodilation. J Appl Physiol (1985). 2009; 106(44): 1264-1271.

PubMed Abstract | Publisher Full Text

Flouris $\mathrm{AD}$, Cheung SS: Thermometry and calorimetry assessment of sweat response during exercise in the heat. Eur J Appl Physiol. 2010; 108(5): 905-911. PubMed Abstract | Publisher Full Text

Flouris AD, Cheung SS: Thermal basis of finger blood flow adaptations during abrupt perturbations in thermal homeostasis. Microcirculation. 2011; 18(1): $56-62$.

PubMed Abstract | Publisher Full Text

Flouris $\mathrm{AD}$, Piantoni $\mathrm{C}$ : Links between thermoregulation and aging in endotherms and ectotherms. Temperature (Austin). 2015; 2(1): 73-85. PubMed Abstract | Publisher Full Text | Free Full Text

Fyfe JC, Meehl GA, England MH, et al:: Making sense of the early-2000s warming slowdown. Nature Clim Change. 2016; 6: 224-228.

Publisher Full Text

Halliwill JR, Sieck DC, Romero SA, et al.: Blood pressure regulation x: what happens when the muscle pump is lost? Post-exercise hypotension and

syncope. Eur J Appl Physiol. 2014; 114(3): 561-578.

PubMed Abstract | Publisher Full Text | Free Full Text

Hawkins E, Edwards T, McNeall D: Pause for thought. Nat Clim Chang. 2014; 4 154-156.

Publisher Full Text

Hulme M: $1.5{ }^{\circ} \mathrm{C}$ and climate research after the paris agreement. Nat Clim Chang. 2016; 6: 222-224.

Publisher Full Text

Ineson S, Maycock AC, Gray LJ, et al:: Regional climate impacts of a possible future grand solar minimum. Nat Commun. 2015; 6: 7535 .

PubMed Abstract | Publisher Full Text | Free Full Text

IPCC: Climate change 2014: Synthesis report. Contribution of working groups iii and iii to the fifth assessment report of the intergovernmental panel on climate change Geneva, Switzerland: IPCC. 2014.

Reference Source

Kenny GP, Journeay WS: Human thermoregulation: Separating thermal and nonthermal effects on heat loss. Front Biosci (Landmark Ed). 2010; 15: 259-290. PubMed Abstract | Publisher Full Text

Kenny GP, Jay O: Thermometry, calorimetry, and mean body temperature during heat stress. Compr Physiol. 2013; 3(4): 1689-1719.

PubMed Abstract | Publisher Full Text

Kenny GP, Stapleton JM, Yardley JE, et al.: Older adults with type 2 diabetes store more heat during exercise. Med Sci Sports Exerc. 2013; 45(10): 1906-1914. PubMed Abstract | Publisher Full Text

Kenny GP, Larose J, Wright-Beatty HE, et al:: Older firefighters are susceptible to age-related impairments in heat dissipation. Med Sci Sports Exerc. 2015; 47(6): 1281-1290

PubMed Abstract | Publisher Full Text

Kenny GP, Poirier MP, Metsios GS, et al: Hyperthermia and cardiovascular strain during an extreme heat exposure in young versus older adults.

Temperature. (In press); 1-10.

Publisher Full Text

Lossius K, Eriksen M, Walløe L: Fluctuations in blood flow to acral skin in humans: Connection with heart rate and blood pressure variability. $J$ Physiol. 1993; 460(1): 641-655.

PubMed Abstract | Publisher Full Text | Free Full Text

Luber G, McGeehin M: Climate change and extreme heat events. Am J Prev Med. 2008; 35(5): 429-435.

PubMed Abstract | Publisher Full Text

Meade RD, Poirier MP, Flouris AD, et al:: Do the Threshold Limit Values for Work in Hot Conditions Adequately Protect Workers? Med Sci Sports Exerc. 2016; 48(6): 1187-1196

PubMed Abstract | Publisher Full Text

Nieves V, Willis JK, Patzert WC: GLOBAL WARMING. Recent hiatus caused by decadal shift in Indo-Pacific heating. Science. 2015; 349(6247): 532-535. PubMed Abstract | Publisher Full Text

Solomon S, Daniel JS, Neely RR 3rd, et al.: The persistently variable "background" stratospheric aerosol layer and global climate change. Science. 2011; 333(6044): 866-870.

PubMed Abstract | Publisher Full Text

Stapleton JM, Larose J, Simpson C, et al.: Do older adults experience greater thermal strain during heat waves? Appl Physiol Nutr Metab. 2014; 39(3): 292-298. PubMed Abstract | Publisher Full Text

Stapleton JM, Poirier MP, Flouris AD, et al.: Aging impairs heat loss, but when does it matter? J Appl Physiol (1985). 2015; 118(3): 299-309.

PubMed Abstract | Publisher Full Text | Free Full Text

Taylor NA, Tipton MJ, Kenny GP: Considerations for the measurement of core, skin and mean body temperatures. J Therm Biol. 2014; 46: 72-101.

PubMed Abstract | Publisher Full Text

Thoma M, Greatbatch RJ, Kadow C, et al:: Decadal hindcasts initialized using observed surface wind stress: Evaluation and prediction out to 2024. Geophys Res Lett. 2015; 42(15): 6454-6461.

Publisher Full Text

Tollefson J: Climate change: The forecast for 2018 is cloudy with record heat. Nature. 2013; 499(7457): 139-141.

PubMed Abstract | Publisher Full Text

Trenberth KE: CLIMATE CHANGE. Has there been a hiatus? Science. 2015; 349(6249): 691-692.

PubMed Abstract | Publisher Full Text

Webb P: Afterdrop of body temperature during rewarming: an alternative explanation. J Appl Physiol (1985). 1986; 60(2): 385-390.

PubMed Abstract

Webb P: The physiology of heat regulation. Am J Physiol. 1995; 268(4 Pt 2): R838-850.

PubMed Abstract

World Meteorological Organization, World Health Organization: Heatwaves and health: Guidance on warning-system development. Geneva, Switzerland: World Meteorological Organization. 2015

Reference Source 


\section{Open Peer Review}

\section{Current Peer Review Status:}

\section{Version 1}

Reviewer Report 08 March 2017

https://doi.org/10.5256/f1000research.11373.r20720

(C) 2017 Kiyatkin E et al. This is an open access peer review report distributed under the terms of the Creative Commons Attribution License, which permits unrestricted use, distribution, and reproduction in any medium, provided the original work is properly cited.

\section{Eugene A. Kiyatkin}

Behavioral Neuroscience Branch, National Institute on Drug Abuse - Intramural Research Program, National Institutes of Health (NIH), Baltimore, MD, USA

\section{Keaton T. Cameron-Burr}

National Institute of Drug Abuse, Intramural Research Program, National Institutes of Health (NIH), Baltimore, MD, USA

Title: Heat remains unaccounted for in thermal physiology and climate change research

Comments:

This opinion piece touches on an important issue. It is critical to accurately measure the redistribution of heat within both climate and physiological systems. The authors correctly note the interconnectedness of the two: as the earth warms, heat-related health risks will rise as the dynamics of energy transfer between organism and environment change. Standards to protect workers and the environment should be updated to reflect the most accurate and helpful measurements and information as is possible.

Major comments:

The authors draw a parallel between heat distribution in human and heat distribution within climate systems throughout the piece. While I see the analogy, it might be best to reign in this comparison in some places, specifically, on page 3 under the heading "Heat parallels in the two disciplines". While the point is well taken, the human body has many mechanisms that actively work to maintain thermo-homeostasis. The earth, on the other hand, is a passive system with no "goal temperature", as it were. Would it be better simply to state that temperature distribution is important in both systems and that our understanding and measurements of it need to be improved in the interest of human health? Given that heat distribution in humans is dependent on the temperature of the environment, there is a strong argument to be made linking these two variables without drawing a comparison between an actively regulated homeostatic system and system in 
which heat distribution occurs through passive mechanisms. The first paragraph of "Unaccounted heat in thermal physiology research" contains this analogy as well.

Minor:

The authors put forward that the findings of Nieves et al. were confirmed by increased temperatures in 2015 and 2016 (Page 2). When considering global trends, single year data is a fraught method of proof given the degree of between-year variability in temperature. By the same logic, the climate change slowdown from 1998-2013 discussed in this paper was used to justify a lack of action around climate change.

Some slightly awkward phrasing persists in this article. For example, the first sentence of the second paragraph on page 2 under "Unaccounted heat in climate research" could be rewritten as "Research aiming to understand the 1998-2013 hiatus significantly benefited from studies investigating the causes...". The sentence, "This is not surprising." Under the same heading on page 2 , does not add to the paragraph and could be cut. "Unaccounted heat in thermal physiology research" could benefit from some discussion of the importance of brain temperature (Kiyaktin 2010 for review $^{1}$ ). Individuals may experience robust changes in brain temperature during behavioral activation such as manual labor or intense exercise that can result, under conditions of diminished heat dissipation, in pathological hyperthermia ${ }^{2}$. Hyperthermia increases permeability of the blood-brain barrier, predisposing individuals to the development of vasogenic edema and damage of brain cells. Increased global temperature may also pose increased health risks for people using psychomotor stimulant drugs of abuse, the effects of which are greatly potentiated by increased ambient temperature. This is critical when considering issues of heat distribution in which peripheral tissues can tolerate greater changes in heat with less threat to the health and survivability of the organism, whereas increases in specific organ structures such as the brain can threaten organism health.

\section{References}

1. Kiyatkin EA: Brain temperature homeostasis: physiological fluctuations and pathological shifts. Front Biosci (Landmark Ed). 2010; 15: 73-92 PubMed Abstract

2. Kiyatkin EA, Sharma HS: Environmental conditions modulate neurotoxic effects of psychomotor stimulant drugs of abuse.Int Rev Neurobiol. 2012; 102: 147-71 PubMed Abstract | Publisher Full Text

Competing Interests: No competing interests were disclosed.

We confirm that we have read this submission and believe that we have an appropriate level of expertise to confirm that it is of an acceptable scientific standard, however we have significant reservations, as outlined above.

Author Response 09 Mar 2017

Andreas Flouris

We wish to thank you for reviewing the manuscript and for your constructive and helpful 
comments. We made appropriate changes in the paper based on your comments. The appropriate responses to all points that you raised appear below with each of your comments in underlined italics and our responses in bold font. Bold underlined font is used to indicate revised parts of the text.

\section{Comments:}

This opinion piece touches on an important issue. It is critical to accurately measure the redistribution of heat within both climate and physiological systems. The authors correctly note the interconnectedness of the two: as the earth warms, heat-related health risks will rise as the dynamics of energy transfer between organism and environment change. Standards to protect workers and the environment should be updated to reflect the most accurate and helpful measurements and information as is possible.

Thank you for your encouraging comments.

Major comments:

The authors draw a parallel between heat distribution in human and heat distribution within climate systems throughout the piece. While I see the analogy, it might be best to reign in this comparison in some places, specifically, on page 3 under the heading "Heat parallels in the two disciplines". While the point is well taken, the human body has many mechanisms that actively work to maintain thermo-homeostasis. The earth, on the other hand, is a passive system with no "goal temperature", as it were. Would it be better simply to state that temperature distribution is important in both systems and that our understanding and measurements of it need to be improved in the interest of human health? Given that heat distribution in humans is dependent on the temperature of the environment, there is a strong argument to be made linking these two variables without drawing a comparison between an actively regulated homeostatic system and system in which heat distribution occurs through passive mechanisms. The first paragraph of "Unaccounted heat in thermal physiology research" contains this analogy as well.

We agree with your observation. Specific comments were added in the relevant sections of the paper to improve clarity.

$1^{\text {st }}$ paragraph of section "Unaccounted heat in thermal physiology research": "Although the Earth is a "passive system" with no active regulation of temperature or heat content (based on current knowledge, that is)...."

$1^{\text {st }}$ paragraph of section "Heat parallels in the two disciplines":

"Heat distribution (and its associated temperature variation) is important in both the Earth and the human body and our understanding and measurements of it need to be improved in the interest of human health (since human thermal homeostasis is largely dependent on environmental temperature)."

Minor:

The authors put forward that the findings of Nieves et al. were confirmed by increased 
temperatures in 2015 and 2016 (Page 2). When considering global trends, single year data is a fraught method of proof given the degree of between-year variability in temperature. By the same logic, the climate change slowdown from 1998-2013 discussed in this paper was used to justify a lack of action around climate change.

To improve clarity, we revised the $1^{\text {st }}$ paragraph of section "Unaccounted heat in climate research" as follows:

"Specifically, Nieves et al., showed that heat moved from the surface of the Pacific Ocean to the deeper layers of the Western Pacific and Indian Oceans, a finding that was confirmed using a wealth of observational and simulated data. As a result, the net ocean heat uptake remains dangerously high (Nieves et al., 2015), and the rate of global warming may have actually increased during the hiatus period (IPCC, 2014). The observed record-breaking temperatures throughout 2015 and 2016 (https://www.nasa.gov/press-release/nasa-noaa-data-show-2016-warmest-year-onrecord-globally) support the findings of Nieves et al."

Some slightly awkward phrasing persists in this article. For example, the first sentence of the second paragraph on page 2 under "Unaccounted heat in climate research" could be re-written as "Research aiming to understand the 1998-2013 hiatus significantly benefited from studies investigating the causes...". The sentence, "This is not surprising." Under the same heading on page 2, does not add to the paragraph and could be cut.

As suggested, the following revisions were done:

"Research aiming to understand the 1998-2013 hiatus significantly benefited from studies investigating the causes of a much longer hiatus observed from the 1950 s to the 1970s."

"This is because ocean circulation..."

"Unaccounted heat in thermal physiology research" could benefit from some discussion of the importance of brain temperature (Kiyaktin 2010 for review1). Individuals may experience robust changes in brain temperature during behavioral activation such as manual labor or intense exercise that can result, under conditions of diminished heat dissipation, in pathological hyperthermia2. Hyperthermia increases permeability of the blood-brain barrier, predisposing individuals to the development of vasogenic edema and damage of brain cells. Increased global temperature may also pose increased health risks for people using psychomotor stimulant drugs of abuse, the effects of which are greatly potentiated by increased ambient temperature. This is critical when considering issues of heat distribution in which peripheral tissues can tolerate greater changes in heat with less threat to the health and survivability of the organism, whereas increases in specific organ structures such as the brain can threaten organism health. As suggested, we added the following sentence in the $1^{\text {st }}$ paragraph of the section entitled "Unaccounted heat in thermal physiology research":

"Moreover, peripheral tissues can tolerate greater changes in heat with less threat to the health and survivability of the organism, whereas increases in specific organ structures such as the brain can threaten organism health (Kiyatkin, 2010)." 
Competing Interests: No competing interests were disclosed.

Reviewer Response 16 Mar 2017

\section{Eugene A. Kiyatkin}

The Authors properly responded to all comments raised in our review.

Competing Interests: No competing interests were disclosed.

Reviewer Report 07 March 2017

https://doi.org/10.5256/f1000research.11373.r20753

(C) 2017 Oksa J. This is an open access peer review report distributed under the terms of the Creative Commons Attribution License, which permits unrestricted use, distribution, and reproduction in any medium, provided the original work is properly cited.

\section{Juha Oksa}

Physical Work Capacity team, Finnish Institute of Occupational Health, Oulu, Finland

The opinion article by Dr's Flouris and Kenny nicely describes the similarities in the changes of heat content pattern between the Earth and the human body. The difference between these two is naturally the time frame, the response of the Earth being several years and that of the human, minutes.

Given that Earth is warming, extreme heat wave episodes are increasing and the study the authors are referring to (Meade et al. $2016^{1}$ ) points to the possibility that the existing TLV guidelines may not be sufficient in protecting labor force from excessive heat strain (as the authors state). Therefore, a re-evaluation of the current TLV guidelines might be desirable.

However, it would also be desirable to see previous evaluations regarding the usability and effectiveness of the current guidelines. Has it been successful in preventing excessive heat strain? If not, what has been the causes? This might increase the justification for re-evaluation of the current TLV guidelines.

\section{References}

1. Meade RD, Poirier MP, Flouris AD, Hardcastle SG, et al.: Do the Threshold Limit Values for Work in Hot Conditions Adequately Protect Workers?. Med Sci Sports Exerc. 2016; 48 (6): 1187-96 PubMed Abstract | Publisher Full Text

Competing Interests: No competing interests were disclosed. 
I confirm that I have read this submission and believe that I have an appropriate level of expertise to confirm that it is of an acceptable scientific standard.

Author Response 09 Mar 2017

Andreas Flouris

We wish to thank you for reviewing the manuscript and for your constructive and helpful comments. We made appropriate changes in the paper based on your comments. The appropriate responses to all points that you raised appear below with each of your comments in underlined italics and our responses in bold font. Bold font is used to indicate revised parts of the text.

The opinion article by Dr's Flouris and Kenny nicely describes the similarities in the changes of heat content pattern between the Earth and the human body. The difference between these two is naturally the time frame, the response of the Earth being several years and that of the human, minutes. Given that Earth is warming, extreme heat wave episodes are increasing and the study the authors are referring to (Meade et al. 20161) points to the possibility that the existing TLV guidelines may not be sufficient in protecting labor force from excessive heat strain (as the authors state). Therefore, a re-evaluation of the current TLV guidelines might be desirable. Thank you for your encouraging comments.

However, it would also be desirable to see previous evaluations regarding the usability and effectiveness of the current guidelines. Has it been successful in preventing excessive heat strain? If not, what has been the causes? This might increase the justification for re-evaluation of the current TLV guidelines.

The history of the TLV guidelines starts in 1971 (ACGIH, 2007). However, to the best of our knowledge, the study referenced in our paper is the only one that directly assessed the influence of the work exposure limits outlined in the TLV on core temperature responses during work and the associated changes in whole-body heat content. To clarify this further, we added a relevant comment in the paper [ $2^{\text {nd }}$ paragraph of section "Unaccounted heat in thermal physiology research"]:

"While the history of the TLV guidelines starts in 1971 (ACGIH, 2007), to the best of our knowledge, the aforementioned recent study is the only one that directly assessed the influence of the work exposure limits outlined in the TLV on core temperature responses during work and the associated changes in whole-body heat content."

Competing Interests: No competing interests were disclosed. 
The benefits of publishing with F1000Research:

- Your article is published within days, with no editorial bias

- You can publish traditional articles, null/negative results, case reports, data notes and more

- The peer review process is transparent and collaborative

- Your article is indexed in PubMed after passing peer review

- Dedicated customer support at every stage

For pre-submission enquiries, contact research@f1000.com 